ARTICLE

DOI: $10.1057 /$ s41599-017-0018-z

\title{
'No spoilers, please': the crux of illustrating the explained Gothic without explaining the mystery
}

Susanne Schwertfeger ${ }^{1}$

\begin{abstract}
Besides the story itself, illustrations add an extra layer to how a text is perceived. As related to the Gothic novel, this visual attribute and its specific issues have been hardly addressed. This article focuses on a special aspect of the complicated relationship between the literary and the visual Gothic. How can the Gothic atmosphere be translated from the experience of reading (as an establishing and successive act) into an experience of viewing (which, in the case of these illustrations, is not consecutive but almost isolated and selective)? The article concentrates on a certain dilemma that especially occurs for those stories that can be labeled as explained Gothic, in which no actual ghosts or demons haunt the scene, but banditti or other quite human villains do. The characters in the diegesis as well as the readers were for most of the story unaware of the true nature of the described phenomenon. Therefore, how could this phenomenon be visualized to generate interest (as a selling point) and somehow stay true to the source without giving away the ending at the same time? First, this article offers close readings of various illustrations for Ann Radcliffe's Gothic Novel The Mysteries of Udolpho (1794), in which the artists had to struggle with the depiction of the most famous episode of Emily St. Aubert's attempts to lift the infamous black veil. It identifies three opposing strategies of how this predicament was solved. The aesthetic of reception is used to further analyze those approaches. The article then argues that the strategies are distinguished by the handling of the mystery and understanding of the concept of the explained Gothic in general. Finally, it reconstructs the assumed readership for those different editions and their preferences of the visual Gothic.
\end{abstract}

\footnotetext{
${ }^{1}$ Christian-Albrechts-Universität, Kiel, Germany. Correspondence and requests for materials should be addressed to S.S. (email: schwertfeger@kunstgeschichte.uni-kiel.de)
} 


\section{Introduction}

$t$ the time the Gothic novel grew popular, it also became common practice to furnish its publications with images. Not only because of the technical developments in the field of the letterpress, but also due to an increasingly literate public and a growing competitive market that provided the audience with reading matter, frontispieces and illustrations which were now an aspect of marketing. Illustrations were deployed as special features to advertise book series, moreover, the names of well-known illustrators/artists proved to be an additional drawing point (Maidment, 2008 p 234; Houfe, 1998 $\mathrm{p}$ 315). However, the most beloved form of the genre, the explained Gothic (Castle, 1987) - as brought to maturity by Ann Ward Radcliffe (1764-1823) with its narrative technique of repeated suspense-posed a specific problem for publishers and illustrators of such works: the Gothic novel's attraction to a large extent stemmed from those exact figures and scenes of suspense which made them a predestined motif for a possible illustration as a selling point-while at the same time, both the characters in the diegesis and the readers were for most of the story unaware of the true nature of the phenomena and were to be kept in this state of suspense until the close of the narrative. The illustrators therefore had to develop strategies in visual narration that on the one hand would generate interest in the story based on the seemingly supernatural episodes and on the other would not spoil the mystery.

In order to analyze those strategies of avoiding such spoilers in the enclosed images, this paper compares various illustrations of Ann Radcliffe's Gothic novel The Mysteries of Udolpho (1794) from a Visual Studies perspective. Here, different artists struggled with the depiction of the episode of Emily St. Aubert's attempts to lift the infamous black veil and its translation from text to image: (the question is) which pictorial means were used to evoke the atmosphere of the situation and how could such a shift in perspective be executed? Ann Radcliffe used techniques such as "delays, interruptions, and slumps in the narrative flow" (Schwarz, $2001 \mathrm{p} \mathrm{54)}$ to build up the suspense and to (further) conceal the true cause of these phenomena which filled her characters with terror. The episode of the veiled picture therefore is particularly suitable as the object of research for it not only "became an icon in early Gothic fiction, $[\ldots]$ and it is the most famous instance of Radcliffe's mastery of suspense and its emotional heightening" (Voller, $2006 \mathrm{p}$ 53), but its popularity also generated a range of illustrations: the scene was the most frequently chosen one as a frontispiece or plate for the various illustrated editions of The Mysteries of Udolpho. Each of those printed veil images worked as a suggestion of a scene selection and its pictorial solution for the successors. It also contributed to the canonization of the scene as the significant agent of the story in the perception of the audience.

\section{Sinister fascination and the challenges of the black veil}

The Mysteries of Udolpho was Ann Radcliffe's penultimate novel. Once again, she expanded the features of the Gothic, introduced by Horace Walpole for example, by focusing on the feelings of suspense and terror. It contains several classic elements of the Gothic genre, such as the Byronic villain Signor Montoni, who keeps his newlywed wife and her niece, the young heroine Emily St. Aubert, captive in his decaying castle in the Apennine Mountains. Radcliffe employs the interplay between veiling and unveiling as a device of suspense and terror: locked doors and unexplored passages stimulate the imagination; faces and objects are hidden behind veils and escape identification. As a character shaped by sentiment and whose behavior-following the ideas of the Sublime and the Picturesque-is focused on perception by the "hungry eye" (Gilpin, 1748 p 54) $)^{1}$, it is this deprivation that challenges Emily the most (Kosofsky Sedgwick: 1981). ${ }^{2}$ In Udolpho, the concept of veiling culminates in the black curtain that is located in one of the rooms of the castle. During her wanderings through the labyrinthine corridors, Emily and the servant Annette come across a large picture frame, which is the only one veiled in the gallery. Annette explains that the silk curtain hides a painting that came into the possession of Montoni under mysterious circumstances and although nobody has seen it, "there is something very dreadful belonging to it" (Radcliffe, 1799: 2: 188). Already the unique feature of being under wraps and excluded from the viewer's gaze provides the object with a mysterious aura which is nurtured by the sinister allusions of the servant. This of course challenges the heroine and, throughout the story, Emily makes numerous attempts to lift this veil and to catch a glimpse of what it conceals. On the first occasion, the scared Annette thwarts this endeavor by running off with the only lamp forcing Emily to abort her mission and follow her. But the thought of the mystery which lies behind the veil keeps her tempted and she decides to examine the object on her own.

As she passed through the chambers, that led to this, she found herself somewhat agitated; its connection with the late lady of the castle, and the conversation of Annette, together with the circumstance of the veil, throwing a mystery over the subject, that excited a faint degree of terror. But a terror of this nature, as it occupies and expands the mind, and elevates it to high expectation, is purely sublime, and leads us, by a kind of fascination, to seek even the object, from which we appear to shrink. (Radcliffe, 1799: 2: 231)

This passage not only anticipates the thoughts on the definition and distinction between terror and horror from Radcliffe's article On the Supernatural in Poetry from 1826 (Clery and Miles, 2000 p 168) ${ }^{3}$ but at the same time explains the fascinating appeal that the mysteries of the castle of Udolpho have for Emily. This sense is transferred to the reader and continuously builds up the suspense and the desire to know what is behind the curtain. However, despite Emily finding the courage to lift the veil, there is no release or suspense for the reader. The author does not provide an explanatory description of what the heroine sees. Instead, the narrator changes the perspective by describing the heroine's physical reaction to the situation:

Emily passed on with faltering steps, and having paused a moment at the door, before she attempted to open it, she then hastily entered the chamber, and went towards the picture, which appeared to be enclosed in a frame of uncommon size, that hung in a dark part of the room. She paused again, and then, with a timid hand, lifted the veil; but instantly let it fall-perceiving that what it had concealed was no picture, and, before she could leave the chamber, she dropped senseless on the floor. (Radcliffe, 1799: 1: 404)

The reader witnesses the 'appropriate' physical and psychic reaction of a sensitive and cultivated young woman in the light of what literally seems too horrid to describe. The mystery of what lies behind the veil stays intact.

At this point of the narration, the curtain itself becomes a painfear stimulus (Krohne, 1976 p 31) and subsequently any veil-like image or even the mention of a veil causes Emily to shudder in terror, even after finally having managed to escape Udolpho. Through such a transition of fear and the conditioning of the reader to such stimuli: 
[...] the anxiety situation becomes concrete and is no longer indefinite; fear is directed towards this precise object. Once this anxiety trigger is established, it fulfils its function without the appearance of the supernatural. Thereby, it is a novelty deployed by Radcliffe so that fear can also be initiated without the situation becoming threatening through this consistency of depiction. (Behnke, 2002 p 80)

Ann Radcliffe manages to infuse objects in the narrative with meaning, which results in a transmission of fear. Instead of the supernatural entities, the regular and ordinary objects become triggers of fear. In the narrative, Emily is sure that those objects which appear mysterious hold a piece of the puzzle in understanding what is going on in the castle and how to escape to safety. Therefore, she repeatedly confronts herself with those objects and situations instead of choosing the strategy of avoidance (Hassenstein, $1978 \mathrm{p} 214$ ), which acts as a narrative trope for the reader to feel empathy for Emily and "the presented media contents are experienced as suspenseful" (Wirtz, 2014 p 105).

Ann Radcliffe's writing technique builds this sensation of the veil and its perception in the text which engages the reader over the course of the story. However, illustrators that chose the episode as the lead feature of a frontispiece or as one scene in a restricted number of plates had limited space and different means to engage the viewer and, respectively, the reader.

Because illustration was still a minor part in book production and considered only additional groundwork to the text, few documents exist which illustrate the exact interaction between the author, the publisher, the designer and the engraver. Beside a limited number of artists who made names for themselves, some illustrators can only be identified today by their signatures on the plates. The majority of the designers and engravers of the illustrations remain unknown due to missing records and documents. While some factors such as the number and type of illustration (frontispiece, plate, title-page vignette, etc.) were preset by the format, most of the artistic decisions were most likely ceded to the artist (Hodnett, 1982 p 7) and therefore depended, amongst other things, on his or her knowledge of the story and imaginative and artistic skills. These features, of course, came with a price tag and might not even have been necessary in the eye of every publisher. A solid performance in producing a universally applicable landscape scenery or the depiction of a supernatural scene as, for example, the invocation of the devil from Matthew Gregory Lewis' The Monk, were often considered as sufficient, and straight to the point. However, the task of translating the complex nature of Ann Radcliffe's episode of the veiled picture or even in adapting an existing illustration of it required different strategies from the artists.

\section{Spoiling the mystery}

Considering how Ann Radcliffe manages to lead the reader and her heroine astray, the illustrators, already knowing what lies behind the black veil, nevertheless had to depict the scene's suspense without giving away the mystery: it does not cover a canvas, but a recess in the wall, and (with)in it "a human figure of ghastly paleness, stretched at its length, and dressed in the habiliments of the grave" (Radcliffe, 1799: 4: 399-400). When Emily finally succeeds in lifting the curtain, she mistakes the body that is "partly decayed and disfigured by worms, which were visible on the features and hands", for human and fears that Montoni could have killed his former wife and hidden her corpse. The reader learns in one of the last chapters that she is mistaken and that the body was in fact a wax mannequin used by the former Marquis of Udolpho for contemplation of morality and death. Although the text does not explicitly mention it, the reader can assume that the wax figure had male features for it was, "serving as a memento of the condition at which he [the former Marquis] must himself arrive" (400-401).

The very first visualization of Emily's encounter with the black veil appears in the 1798 French edition by Maradan (1798a; Fig. 1). The company was one of the major publishers in Paris and added novels to its portfolio, which until the turn of the 18th century mainly consisted of theatre literature and medical books (Hesse, 1991 p 196-198). The second of four frontispieces combines different sequences from the text. In it, although the fleeing Annette marks the first encounter with the black veil when Emily has to leave the scene without having accomplished her intention, the curtain is already drawn aside enough so the viewer can peek behind it. The relation between the frame, the visible torso and the dark area behind it here seems ambivalent. The black space can be interpreted as a painted monochrome background of a canvas as there are no signs of spatial expansion. The figure itself, which in the novel is initially mistaken as female by the heroine, can be identified as male in this illustration. Therefore, in the following course of the narrative, the reader would have no reason to engage with Emily's idea and fears that the body could be the Marquise or even her missing aunt. In addition to this, the figure is completely intact without any signs of decay. This, as well as the paraphrased caption, "Vous palissez Annette?" (Radcliffe, 1798a: 2: n. p.), could be the result of artistic freedom but more importantly runs counter to the novel's narrative itself. The content of the image departs from the text and the viewer not only has a noticeable lead in knowledge compared to Emily, but the function of creating terror shifts from the veil to the visible body.

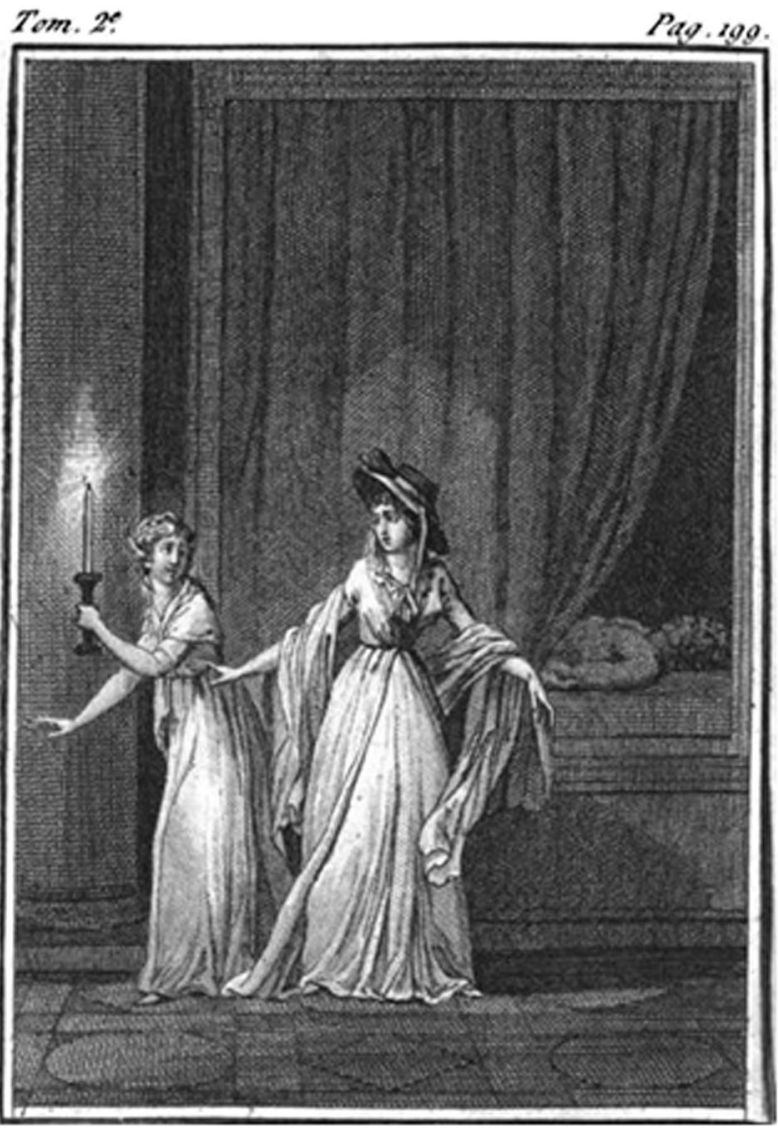

Fig. 1 Vous palissez Annette? Frontispiece by an unknown artist for Les Mystères D'Udolphe, published 1798 by Maradan, Paris. This figure is covered by the Creative Commons Attribution 4.0 International License. The image is in the Public Domain 
Contrastingly to the French edition, a German edition from the same year by Franz Haas allows the viewer to witness the gruesome horror together with the heroine (1798b; Fig. 2). In the vignette of the first of two volumes, the young woman faces the observer, pulling away the curtain with her right hand. The light from her raised torch falls into the small niche behind the drape and the shadows on the laid-out skeleton follow the same lightning scheme so the object is perceived as a three-dimensional figure. Here, the illustrator engages with Ann Radcliffe's unusually explicit depiction of the putrid body, which in this passage leans more towards the style of horror than of terror: worms elongate upwards trough the skull and the ribcage. Emily's inner turmoil when facing this sight is also visible, as her loose locks resemble her exaggerated cloak. This agitation is not caused by physical movement or a certain gust of wind, but signifies her distressed state of mind shortly before she faints in the narrative. ${ }^{4}$ The depiction of the skeleton in the vignette leaves room for interpretation as being the remains of either a woman or a man. However, its pairing in the volume with a frontispiece that shows Madame Montoni threatened by her cruel husband and Emily begging him on her knees to have mercy with her aunt could lead

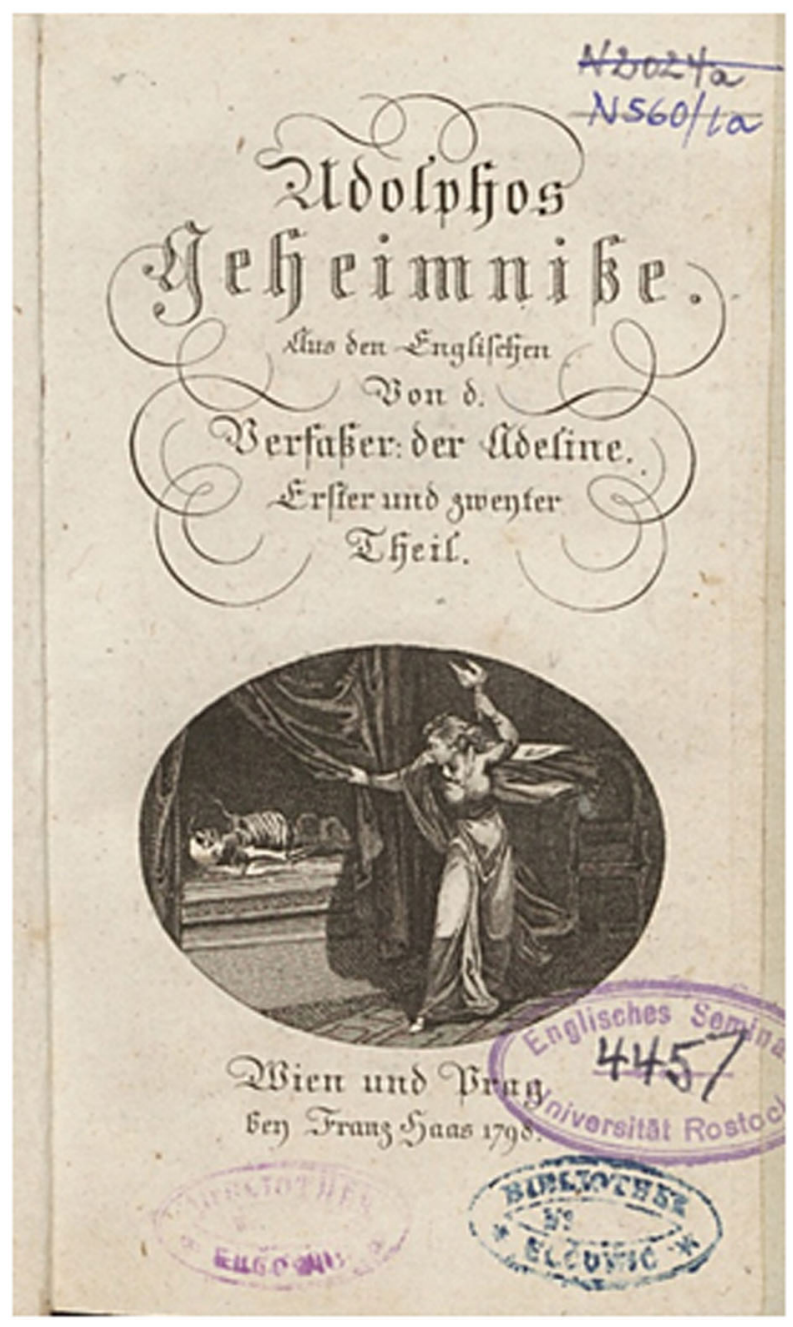

Fig. 2 Title vignette engraved by L[?] Maillard for Udolphos Geheimnisse, published 1798 by F. Haas, Vienna and Prague. This figure is covered by the Creative Commons Attribution 4.0 International License. Reproduced with permission of the Universitätsbibliothek Rostock, 2003 A 10336(1/2); copyright (C) Universitätsbibliothek Rostock, all rights reserved. The image is in the Public Domain to the impression of a textual coherence and reinforce Emily's theories about the body. These choices of motif and their elaboration in a more drastic style echo the former publication of Radcliffe novels by Haas. In 1797, the press had already released Adeline oder die Abentheuer im Walde, ${ }^{5}$ which not only included a vignette with a skeleton but also the exposed breast of a sleeping woman, going far beyond Radcliffe's innocent description of the scene. The emphasis on aspects of horror and sexuality can be judged as marketing strategies following the success of Matthew Lewis' The Monk (1796): its German edition Der Mönch was published in 1797 in Leipzig and was a huge success (Jansen, 1984, p 34).

Both in the French Maradan and the German Haas editions, the illustrators chose to relocate the means of terror from the veil and its mystery to the more obvious shock of the manifest body behind it. These strategies of visualization might be based on the willingness to ignore the suspense created by the veil in the story itself, but above all, they show the lack of pictorial solutions that were able to translate the psychological dimension of the explained Gothic and this episode in particular into a coherent image at this time.

\section{Keeping the secret}

The English editions, on the other hand, were careful not to spoil the events and stuck more closely to the narrative. In order to do so, the veil had to remain placed in front of the hidden object and the focus shifted to the female protagonists Emily and Annette and their affects. Two different schemes were established: Emily was shown alone or with the servant. The latter's character was exaggerated in all of the images in analogy to the story in which she often functioned almost as a comedic sidekick or the overreacting excess. This type of constellation for example was used in the earliest bluebook-adaption of the novel, The Veiled Picture (1802).

The frontispiece shows the dark room of the gallery with Emily and Annette beside the only partially visible, veiled frame (Fig. 3). The heroine has clasped an edge of the black curtain and turns to the servant hiding behind her, handing her the oil lamp. In this scenario, nothing hints at anything other than a picture could be waiting behind the fabric. The lower edge of the elaborately drawn frame is placed on the same level as Emily's shoulder, which, together with the indicated huge measurements, alludes to the conventions of exhibiting paintings. In contrast to the earlier illustrations from Germany and France, in this frontispiece of The Veiled Picture the actual placing of the recess in the wall with a wax figure in it, displayed for contemplation, seems almost impossible because of the difficult sightlines due to the height at which it is fixed. Through this arrangement, not only the rumor of a hidden canvas from the text is further supported but also the concept of the explained Gothic.

In this pictorial solution of the Veiled Picture frontispiece, the deeper impact on the scene by a figure like Annette is also distinct: not only does she offer comic relief in a suspenseful situation, but her fearful reaction is a necessary marker for Gothic terror. She is shown slightly crouched and with an anxiously furrowed brow beside the curious but calm Emily St. Aubert, whose determination makes Annette's visible apprehension appear even more timorous. Annette's body language and facial expression translate the possible threat and feelings of anxiety for the viewer while Emily is allowed to remain the daring heroine. Without the servant as her counterpart, the tension of the scene would have to be communicated through the figure of the heroine alone. In addition, this would create a different approach to Emily and her characterization, which can be observed in the following examples. 


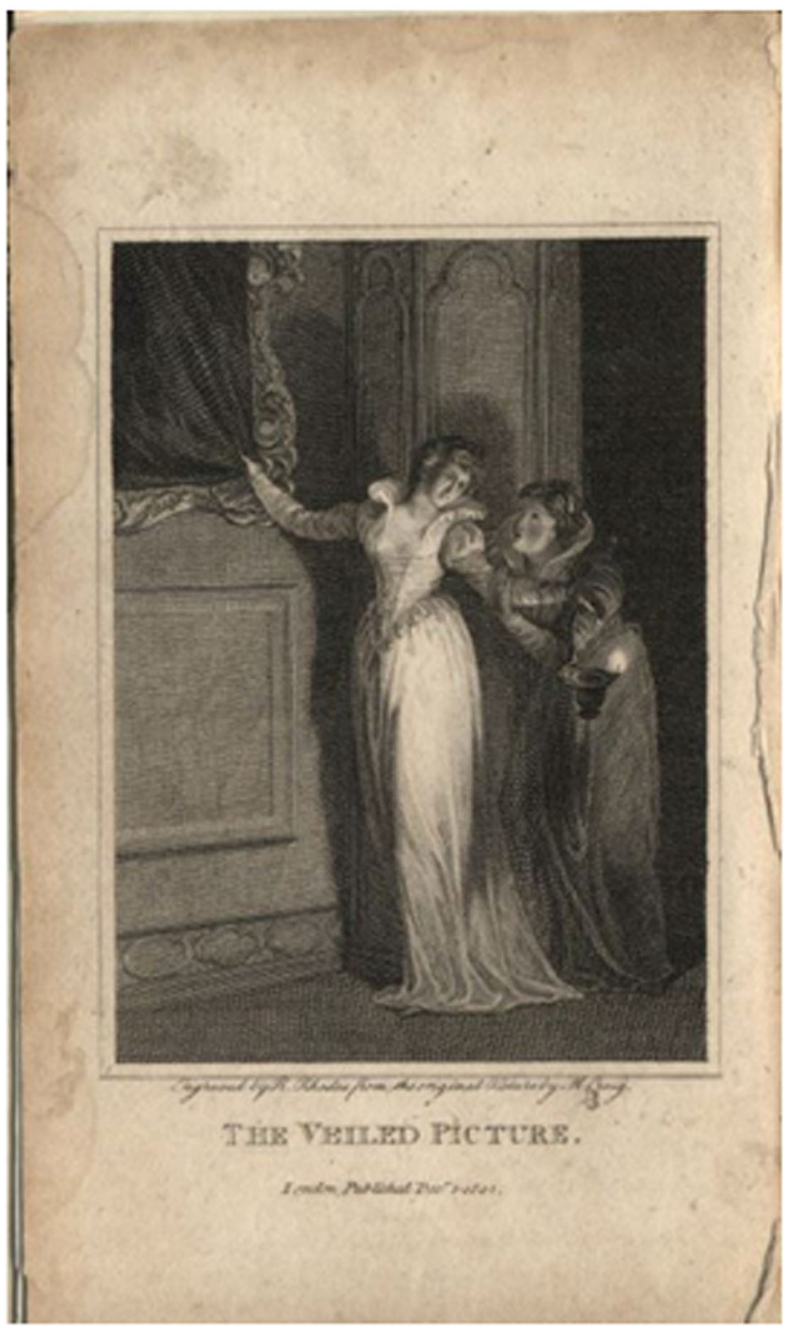

Fig. 3 Frontispiece by an unknown artist for The Veiled Picture, published 1802 by T. Plummer. This figure is covered by the Creative Commons Attribution 4.0 International License. Reproduced with permission of the University of North Carolina at Chapel Hill; copyright (c) University of North Carolina, all rights reserved.The image is in the Public Domain

Two illustrations published in the 1820 s demonstrate the artist's struggle with, on the one hand, wanting to create a suggestive picture and, on the other, keeping both the secret and Emily's integrity intact. For the older one, a chapbook published every other week in thirteen chapters between May and August 1823 by S. Fisher (Fig. 4), William Hopwood (1784-1853) ${ }^{6}$ adapted a scheme that depicts dependences to the outline of the Maradan edition (Fig. 1) and The Veiled Picture (Fig. 3). The body of the heroine is again positioned towards the viewer, her arms are spread wide and her right hand grabs the fabric behind her. Her movement is directed away from the veiled picture while her face showing an expression of fear is turned towards the revealed object. Because of the chosen angle, the source of her terror cannot be seen and the viewer remains in ignorance. Furthermore, Emily's stepping away from the veil while at the same time not being able to keep her eyes from it depicts the ambivalent situation the heroine finds herself in. Her ambiguous pose is accompanied and determined by a caption that informs the reader/viewer about the fate of the young woman: "Emily with a timid hand, lifted the Veil, but with horror let it fall, and dropped senseless on the floor. (Page 259.)" (Radcliffe, 1823). The text here is necessary to complete the narrative and to

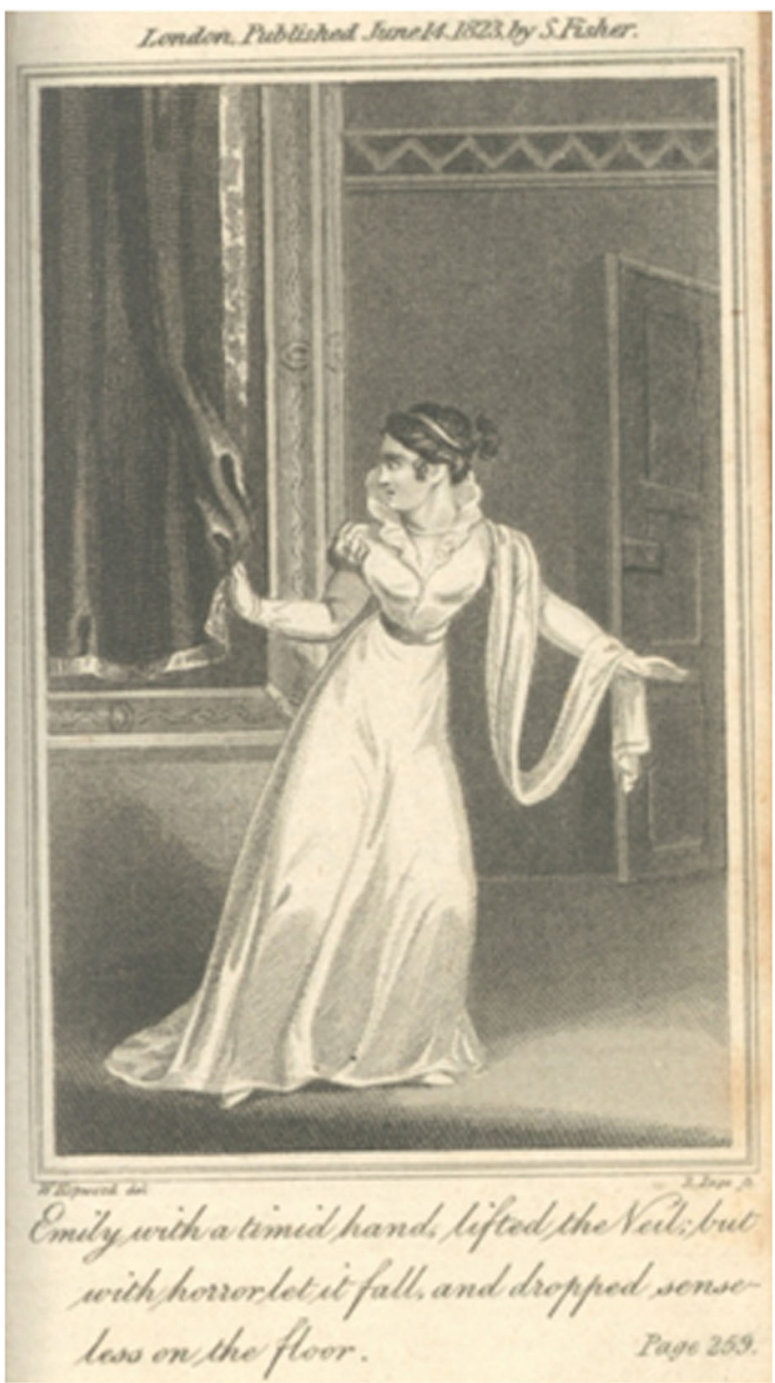

Fig. 4 "Emily with a timid hand, lifted the Veil, but with horror let it fall, and dropped senseless on the floor." Frontispiece by William Hopwood for The Mysteries of Udolpho: A Romance, published 1823 by S. Fisher, London. This figure is covered by the Creative Commons Attribution 4.0 International License. Reproduced with permission of the University of South Carolina; copyright (c) University of South Carolina, all rights reserved. The image is in the Public Domain

intensify the terror, whereas the other images discussed above do not necessarily have to rely on an accompanying text.

This solution from the Fisher edition corresponds with the passage in the text when the focus shifts from the heroine's perception and thoughts towards her re-action, not the action itself.' Therefore also the tactic of the explained Gothic and Ann Radcliffe's narrating technique are inherent.

Another rather low-priced but generously illustrated edition of The Mysteries of Udolpho was published by John Limbird in 1824 (Fig. 5). Using a space-saving, two-column format not only made it possible to print the complete novel in one volume, it also provided the possibility to leave horizontal head ends above the columns. The twenty headpieces were designed by Matthew Sears, ${ }^{8}$ who frequently illustrated Limbird's novel series. ${ }^{9}$ In his version, he also favors the impression of an exhibited painting and shows the veiled frame in the center between two life-sized portraits. The frontal and centralized setup provides easy access to the scene and gives it a high degree of legibility. This is a recurring formula for the Limbird illustrations that seem to 


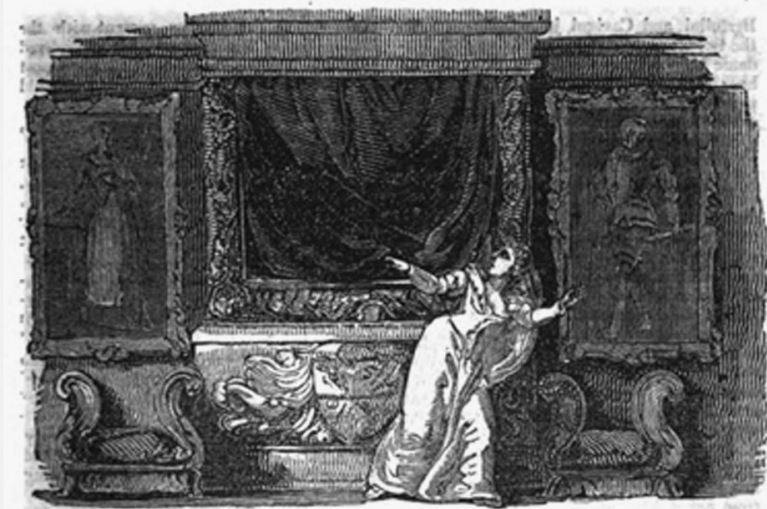

Fig. 5 Illustration by Matthew Urlwin Sears for The Mysteries of Udolpho, published 1826 by Limbird's Edition of the British Novelist', London. This figure is covered by the Creative Commons Attribution 4.0 International License. The image is in the Public Domain

address an audience without highly-educated, visual skills. In this particular motif, it also leads to a uniquely direct confrontation between the viewer and the black veil, which almost marginalizes Emily's figure. Her posture here repeats the one from the Fisher chapbook (Fig. 4): the pose as well as the torsion of her body and head are similar-only the angles of her arms differ slightly. Doerksen interpreted her pose as falling towards the ground because the young woman had just glanced behind the veil and now let the fabric slide back (2011 p 497). ${ }^{10}$ Instead, as in the case of the Fisher frontispiece, the figure again can be read as fleeing or rather indecisive. Furthermore, as this time there is no caption stating her subsequent fainting, the original French Maradan misen-scene, from which the Fisher images heavily borrows, is even further diluted into a simple 'escaping the situation' setting.

Both the Fisher and Limbird solutions described above circumvent the problem of exposing the discrepancy between Emily's first interpretation of what she has witnessed and what really happened. At the same time, they offer only a few narrative elements that the viewer could engage with.

In the 1830 s, another edition for the broad market was published and the signature scene of the black veil was chosen as the motif for one of the two frontispieces (Fig. 6). ${ }^{11}$ It appeared in the series Dove's English Classics by J. F. Dove in a small format that was fitting for a lengthy reading session and with an uniformed design of the book covers that was intended to spark the desire to collect and complete the series. ${ }^{12}$ Including the novels in an English Classic Series contributed to the legitimization of the Gothic titles as belonging to the English literary canon. It was a common feature for such series to contain images. In the Dove edition of the Mysteries of Udolpho, the artist was Henry Corbould (1787-1844), ${ }^{13}$ son of Richard Corbould (1757-1831), who also was an artist known mostly for his landscapes. In his version of the episode, he returns to the older two-person scheme as used by Maradan (Fig. 1) and The Veiled Picture (Fig. 3). The structure of the latter is almost mirrored vertically in Corbould's design with its slanted course of the wall, the heavily cut veil, and the anxiously crouched Annette. ${ }^{14}$ However, the artist changed the angle of Emily's head: her gaze is still fixed onto the veil, her chin is slightly lifted and therefore she appears to be challenging her undertaking. Her expressions do not give away too much of her possible emotions and she has already grabbed an edge of the veil. The composition addresses the viewer directly. Although it is Emily's bright dress that catches the viewer's attention first, it is the anxious face of Annette enlightened by the lamp she is carrying that is emphasized even more through the contrast of the

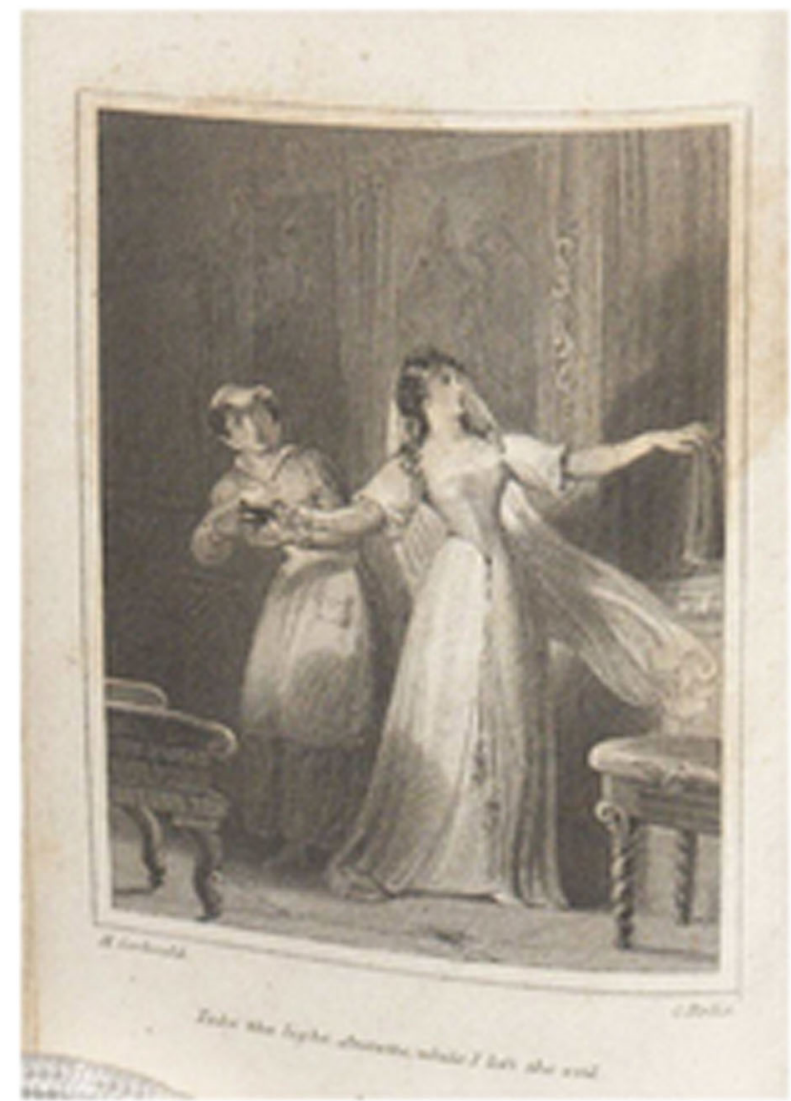

Fig. 6 "Take the light Annette while I lift the veil" Frontispiece by $\mathrm{H}$ [enry] Corbould for The Mysteries of Udolpho, published 183[?] by Doves English Classics, London. This figure is covered by the Creative Commons

Attribution 4.0 International License. Reproduced with permission of the University of Virginia Library; copyright (c) University of Virginia Library, all rights reserved. The image is in the Public Domain

dark sphere surrounding her. The servant's posture is slightly angled to the left, indicating her unease and wanting to flee the situation. Because of this mis-en-scene Emily remains the focus, but her companion's position is crucial to the understanding and the building of suspense in this setting: Annette's right arm and her cowered head are the starting point of an ascending composition line that is continued via Emily's gesture, raising her head and the left arm towards the curtain. ${ }^{15}$ This 'opening' structure is supported by the lighting: the light cone grows from Annette and finds its widest range on the right side. Here, the accentuation through contrast from the left is answered by Emily's pale hand, framed by its dark shadow, again connecting the fear with its trigger. The caption, "Take the light Annette while I lift the veil", only describes what can be seen. Despite not adding to the narrative, it supports Emily as an adventurous and active character. Through the composition with the heroine pulling the fabric away from the viewer's perspective, the impression is given that at the very moment Emily lifts the veil the viewer would also see what lies behind it. Neither The Veiled Picture nor the Limbird edition (Fig. 5) convey this action as a shared experience for heroine and viewer. In line with the story, Corbould includes the initial setup of the contemplation context: Opposite the wall, an armchair provides the possibility to rest in front of the niche and sink into one's own thoughts. Both the chair and the veiled frame in front of it are bound on a visual level as they are heavily cut by the borders of the image field. This arrangement can be 'read' and fully understood after the final 
unveiling of the mystery. Before that, it further fuels the disregard and distrust against Signor Montoni and his implied behavior of spending time immersed in what at this point is believed to be a picture with "something very dreadful belonging to it".

\section{A different kind of mystery-a different kind of audience?}

In one way or the other, the female characters of the episode both depict and contribute to the discourse on womanhood. The more cheaply produced books, in which less effort went into developing an original version of the scene (Fisher, Limbird), stuck to a more widely accepted understanding of femininity as a passive, emotional and vulnerable state, reflecting the common perception of the Gothic heroine as a type especially present in the female Gothic (Bronfen, 1994). On the other hand, editions from publishers who left artistic space and financial scope for new solutions by their illustrators seem to lean towards a more selfdetermined interpretation of the heroine. The press of J. Robinson definitely fell into this latter spectrum (DeLucia, 2015). In 1794, Robinson had bought the manuscript from Ann Radcliffe and in 1799 added four frontispieces to the then released fourth edition (Fig. 7), which made it the very first illustrated edition in England. The third image seems to be dedicated to the veil episode and shows Emily alone with an oil lamp raised in her right hand. With her left she draws back the dark, picture-dominating

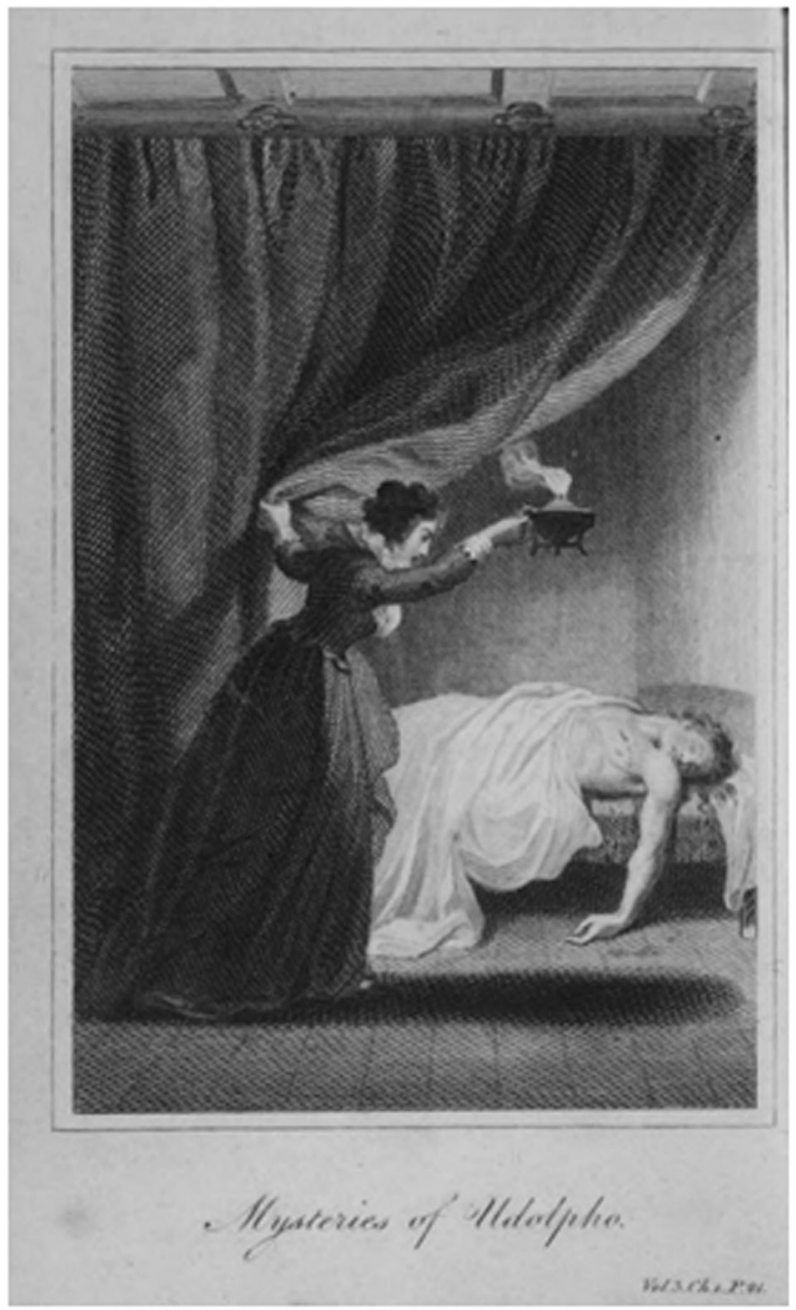

Fig. 7 Frontispiece by an unknown artist for The Mysteries of Udolpho, published 1799 by G G and J Robinson, London. This figure is covered by the Creative Commons Attribution 4.0 International License. The image is in the Public Domain curtain and reveals to the viewer's gaze a male body stretched out on a bed. This frontispiece opens the volume following the one that includes the infamous passage in which Emily faints after actually having managed to lift the veil. Therefore, this image endorses her communicated impression of a figure. However, in this case, the frontispiece does not spoil the mystery of the black veil hanging in the gallery. What is in fact depicted is another curtain from the storyline found in the torture chamber of the castle. Behind it, the body of a soldier killed in an attack by enemy troops against Montoni is lying in state. It has been suggested that the image of the corpse signifies the intention of the publisher to imply to the reader that the novel was "designed to inspire horror as well as terror" (Doerksen, 2011, p 492). Yet the torso in the frontispiece appears in almost perfect condition, except for the wound in his chest which has left traces of blood on the floor, while in the book his features are labeled as "deformed by death" and "ghastly and horrible" (Radcliffe, 1799: 3: 68). Here, the horror has not only been reduced by minimizing the visual wounds, but also actually aestheticized through the usage of a popular and commonly known and thus recognizable iconography depicted at that time in the high arts. The pose can be read as a variation on Fuseli's Nightmare (1781), which had been echoed in numerous forms since its debut and was widely known. Also, in this illustration, Emily's posture does not correspond with the concept of the anxious and sensitive young woman: she not only keeps the curtain away with a dynamic gesture, but bends over, lighting the body, and even seems to examine the situation carefully. Together with the heroine, the viewer can explore the features presented and is able to decode them as borrowed from the high arts.

The Robinson illustrations do not include captions. The impression of a curious and proactive female is not narrowed by the following events as stated in the novel and for example added in the Fisher version (Fig. 4). Nothing indicates her fainting or fleeing, yet the scene is mysterious enough to provoke interest and a sense of fear for the heroine.

Although the Robinson set of images was the most re-printed for The Mysteries of Udolpho in the 19th century, the choice of including the curtain-motif expected by the reader but still not spoiling the actual Mystery of Udolpho was not taken up by later English artists. ${ }^{16}$ The Robinson illustrations address an audience that was not only familiar with a certain discourse on art and had fundamentally educated visual skills but also entertained a different viewpoint on female roles.

\section{Conclusion}

The black veil has been one of the most used motifs from the range of the possible episodes to illustrate from The Mysteries of Udolpho. Ann Radcliffe carefully built up the tension around this mystery and the novel exemplifies her signature style of narration, which later became known as the popular, explained Gothic. The author actually held off on solving the mystery until the last segment of the book and even separated the resolution from the heroine's storyline. She focused on Emily's physical and emotional reactions in her endeavor to lift the veil and the things she sees-or imagines-behind it. The prominence of the novel and the notoriety of the black veil might have created a certain amount of curiosity for the reader that could be fueled by the illustration before actually starting to read the novel.

The complex mechanisms of engaging the reader and immersing them into the diegesis could not be simplified by a single frontispiece or even a sequence of illustrations. The examples discussed above show that the illustrators approached the motif of the mysterious veil and Emily's challenge in different ways. The opposing strategies are distinguished by the handling 
of the mystery and understanding of the concept of the explained Gothic. The first French and German illustrations by Maradan and Haas spoil the mystery by depicting the gruesome image which Radcliffe only described at the end of her novel. In these examples, the cause of Emily's expression of terror is visible and the veil itself becomes secondary. Also, the viewer is addressed directly and can perceive terror because of the body behind the curtain, and Emily is not necessarily needed as an arbitress. In the depiction of the body, the illustrators did not differentiate between the portrayal of a human corpse or an effigy made of wax. The viewer is therefore misguided by his/her sense of sight as much as the heroine is.

The English artists, providing prints for Fisher, Limbird or Dove, leave the mystery intact by not illustrating what lies behind the veil. The illustrators' aspiration to commit to the genre of the explained Gothic is noticeable and in order to do so they converted the textual narrative into a visual one. Their images do not explain more than could be read in this exact paragraph nor add to the story and visualize without anticipating the final identification. Instead, those motifs concentrate on the act of revealing and magnify the stages of lifting or Emily reacting to what she thinks she has seen. Here, the veil could allude to its function in the text as a pain-fear stimulus, without being sidelined by the sensational object behind it. Nevertheless, even in these images the focus is mostly on the human characters. The depiction of the episode offers two different type of women: the anxious, overwhelmed, and vulnerable woman driven by her emotions, in opposition to a curious and exploratory type. If only Emily was shown, it was her duty to express the fear and terror originating from the situation. If accompanied by Annette, the representation of those (female) characteristics were left to the servant. Analogous to the novel, the latter is used to exemplify the suspense which can be exaggerated to oscillate into the comic spectrum.

The decision to use the episode of the black veil revealed the challenges of illustrating the explained Gothic. Not before the enlightenment were the supernatural or the fear that rose from it decoupled from a manifest representation such as a demon or the devil. Even the inner struggle with for example temptations could be depicted through the vehicle that represented the allurement. In her novel, Ann Radcliffe leaves a blank space for the reader to fill in with his/her speculations and emotions induced by Emily's thoughts and her physical reaction. The illustrations provide a visual paratext that offered a reading before stepping into the Gothic tale, but a translation of the narrative trope of omission into visual means did not necessarily result in an engaging image.

Received: 13 December 2016 Accepted: 2 October 2017

Published online: 31 October 2017

\section{Notes}

1 "After surfeiting itself with the Feast here provided for it, the Eye, by using a little Exercise in travelling about the Country, grows hungry again, and returns to the Entertainment with fresh Appetite".

2 Broadwell (1975: 77) states that "Emily's sensibility or subjectivity turns out to be a type of veil". This particular veil prevents her from classifying the things she witnesses correctly.

3 "Terror and horror are so far opposite, that the first expands the soul, and awakens the faculties to a high degree of life; the other contracts, freezes, and nearly annihilates them" (Clery and Miles, 2000: 168).

4 The torch also emphasizes the dramatic moment. Its open, flickering flame in this illustration replaces the usually utilized lamp, which would give a more 'tamed' effect. It is most likely a purposive choice, for Radcliffe does not specify the nature of the light source in this episode.

5 The Romance in the Forest (1791).
6 Little is known about William Hopwood, other than that he was the son of the engraver James Hopwood the Elder and exhibited in the Royal Academy from 1801 to 1804 . He engraved some portraits after original paintings but also executed his own designs, for example, a series of scenes from The Two Gentlemen of Verona by Shakespeare together with his father (Benezit, 2012: 578).

7 This is a consistent characteristic in the illustrations to the S. Fisher edition in which Emily's range of gestures is limited to melodramatically throwing her arms in the air or wringing her hands in despair. Content-wise and in its formalistic and didactic approaches to womanhood, the Fisher frontispieces can be linked to the illustrations in periodicals. As Bennett (1981) pointed out, here since the 1780 s a conjunction between sexuality, brutality and death was made and females were staged as objectified victims. They were shown in various states of grief, love and fear to awake compassion and concern in the viewer.

8 Although Matthew Urlwin Sears seems to have been one of the few regular illustrators for Limbird who worked for both the press's novels and The Mirror of Literature, Amusement, and Instruction magazine, there are almost no details known about his biographical data. He was active in London in the 1820 and worked in Paris (1835-10) and Leipzig. Because of him signing his prints, his oeuvre can be outlined and W. J. Linton commented on him in his The Masters of Wood Engraving (1889): "Sears had enough of graver power to use the white line-vigorously but little of an artist, and with no taste". (Morris, 1931: 112)

9 The technique used here is woodcut, which was predominantly used for illustrations for less expensive publications in the 1820s. In comparison to copperplate illustration molds, the woodcut printing blocks were both more inexpensive and faster to produce.

10 "One arm is outstretched towards the picture, the other towards the door, and her eyes widen with horror as she falls towards the ground".

11 In some catalogues an uncertain year of publication is given, which sets the date round about the 1850s. But given the fact that most of the parts of Dove's English Classics were published between 1825 and 1835 and Courbould's death occurred in 1844 , it is safe to date this particular edition not later than the late 1830 s as, for example, it is listed in the Harvard library.

12 This marketing strategy came up at the end of the 18th century as Ezell states in her analysis of Cooke's Pocket Edition of Select British Poets (Ezell, 1994).

13 Henry Corbould studied at the Royal Academy and earned a solid reputation for his paintings but is even better known for his drawings and his designs for engravings. He worked together with his father as an illustrator in London. Henry contributed a number of illustrations to publications by J. F. Dove including an edition of John Gays Fables in 1826 .

14 Another allusion towards Courbould's knowledge of the older illustration is the belt. This element functions as a reference to the medieval times and is missing in both the Fisher as well as the Limbird image.

15 It is the difference in the depicted turn of Emily's head, as the angle changes the tone of the scene in comparison to the scheme from The Veiled Picture. In the latter, although the composition line also ascends towards the curtain, her torsion emphasizes the interaction with Annette, rather than drawing the viewer's attention to the upcoming events.

16 The disposition of the curtain and the body behind it might be reflected in the Maradan frontispiece (Fig. 1), what would explain the statue-like and also unscathed body.

\section{References}

Behnke K (2002) Der inszenierte Schrecken: Darstellungsstrategien der Angst im englischen Schauerroman. Thesis, (PhD). University of Bielefeld

Benezit (2012) Dictionary of British Graphic Artists and Illustrators. Oxford University Press, New York

Bennett SM (1981) Changing Images of Women in Late-eighteenth-century England: The 'Lady's Magazine,' 1770-1810. Arts Mag 55 (1981):138-141

Broadwell EP (1975) The Veil Image in Ann Radcliffe's The Italian. S Atl Bull 40 (1975):76-87

Bronfen E (1994) Nur über ihre Leiche: Tod, Weiblichkeit und Ästhetik. Königshausen \& Neumann, München

Castle T (1987) The Spectralization of the Other in 'The Mysteries of Udolpho'. In Nussbaum F, Brown L (eds) The New Eighteenth Century: Theory-Politics -English Literature. Methuen, New York and London, p 231-253

Clery EJ, Miles R (2000) Gothic Documents: A Sourcebook 1700-1820. Manchester University Press, Manchester

DeLucia JM (2015) Radcliffe, George Robinson, and Eighteenth-Century PrintCulture: Beyond the Circulating Library. Women's Writ 22 (2015):287-299

Doerksen T (2011) Framing the Narrative: Illustration and Pictorial Prose in Burney and Radcliffe. In: Ionescu C (ed) Book Illustration in the Long Eighteenth Century: Reconfiguring the Visual Periphery of the Text. Cambridge Scholars Publishing, Newcastle, p 463-500

Ezell MJM (1994) Making a classic: The advent of the literary series. S Cent Rev 11 (1994):2-16

Gilpin W (1748) A Dialogue upon the Gardens of the Right Honourable the Lord Viscount Cobham, at Stow in Buckinghamshire. B Seeley, London 
Hassenstein B (1978) Verhaltensbiologie des Kindes. Piper, Munich

Hesse C (1991) Publishing and Cultural Politics in Revolutionary Paris: 1789-1810. University of California Press, Berkeley

Hodnett E (1982) Image and Text. Studies in the Illustration of English Literature. Scolar Press, London

Houfe S (1998) The Dictionary of 19th Century British Book Illustrators and Caricaturists. Antique Collectors' Club, Woodbridge

Jansen PK (1984) 'Monk Lewis' und Heinrich von Kleist. Kleist-Jahrbuch 25-54

Kosofsky Sedgwick E (1981) The Character in the Veil: Imagery of the Surface in the Gothic Novel. Publ Mod Lang Assoc 96 (1981):225-270

Krohne HW (1976) Theorien zur Angst. Kohlhammer, Stuttgart

Maidment B (2008) The Mysteries of Reading; Text and Illustration in the Fiction of G.W.M. Reynolds. In: Humpherys A, James L (eds) G.W.M. Reynolds. Nineteenth-Century Fiction, Politics, and the Press. Ashgate Publishing Company, Hampshire, p 225-246

Morris R (1931) Some forgotten Wood Engravers. Artwork A Q 7(1931):108-112

Radcliffe A (1799) The Mysteries of Udolpho: A Romance. G G and J Robinson, London, $(1 ; 3)$

Radcliffe A (1798a) Les Mystères D’Udolphe. Maradan, Libraire, rue da Cimetiere andre-des-Arts, Paris, (2)

Radcliffe A (1798b) Udolphos Geheimnisse. F Haas, Vienna and Prague, (1)

Radcliffe A (1823) The Mysteries of Udolpho: A Romance. S Fisher, London

Radcliffe A (1826) The Mysteries of Udolpho. Limbird's Edition of the British Novelist', London

Radcliffe A (183[?]) The Mysteries of Udolpho. (1). Doves English Classics, London

Reeve C (1778) The Old English Baron: A Gothic Story. E and C Dilly, London

Schwarz E (2001) Der phantastische Kriminalroman: Untersuchungen zu Parallelen zwischen roman policier, conte fantastique und gothic novel. Thesis, (PhD). University of Gießen

Voller JG (2006) Introduction. In: Voller J (ed) The Veiled Picture. Valancourt Books, Chicago, IL, p 7-14. [1802]

Wirtz MA (2014) Dorsch. Lexikon der Psychologie, 17th edn. Hans Huber, Bern

\section{Data availability}

Data sharing is not applicable to this paper as no datasets were analyzed or generated.

\section{Acknowledgement}

I acknowledge financial support by Land Schleswig-Holstein within the funding programme Open Access Publikationsfonds.

\section{Additional information}

\section{Competing interests}

The author declares that they have no competing financial interests.

Reprints and permission information is available online at http://www.nature.com/ reprints

Publisher's note: Springer Nature remains neutral with regard to jurisdictional claims in published maps and institutional affiliations.

(c) (i)

Open Access This article is licensed under a Creative Commons Attribution 4.0 International License, which permits use, sharing, adaptation, distribution and reproduction in any medium or format, as long as you give appropriate credit to the original author(s) and the source, provide a link to the Creative Commons license, and indicate if changes were made. The images or other third party material in this article are included in the article's Creative Commons license, unless indicated otherwise in a credit line to the material. If material is not included in the article's Creative Commons license and your intended use is not permitted by statutory regulation or exceeds the permitted use, you will need to obtain permission directly from the copyright holder. To view a copy of this license, visit http://creativecommons.org/ licenses/by/4.0/

(C) The Author(s) 2017 